\title{
HUBUNGAN PENGALAMAN PERAWAT DAN KEBERHASILAN RESUSITASI JANTUNG PARU DI RUANG IGD, ICU DAN ICCU RSUD PROF.W.Z JOHANNES KUPANG
}

\author{
Yoani Maria Vianney Bita Aty ${ }^{1}$, Gadur Blasius ${ }^{2}$ \\ ${ }^{1,2}$ Prodi Pendidikan Profesi Ners Poltekkes Kemenkes Kupang \\ Email : ${ }^{1}$ vivi aty@yahoo.co.id \\ Email:1'gadurblasius73@gmail.com
}

\begin{abstract}
ABSTRAC
Cardiovascular disease is a global threat and is the number one cause of death worldwide. Until now, $C P R$ is a very vital management in cases of cardiac arrest. The results of the initial survey found that nurses often found patients who had cardiac arrest, which required CPR. Some patients were saved and some died. Based on this, it is necessary to conduct research on the experience of ER, ICU and ICCU nurses in performing cardiopulmonary resuscitation. The aim of the study was to determine the relationship between nurses' experience and the success of cardiopulmonary resuscitation in the ER, ICU and ICCU RSUD Prof. Dr. W. Z. Johannes Kupang. This research is a quantitative research, correlation study design. The sample used is 41 nurses. Quota sampling technique. Analysis using Chi Square. The results showed that most of the respondents had sufficient experience of cardiopulmonary resuscitation, namely 37 people (90.8\%). Most of the respondents managed to perform CPR, namely 34 people (82.9\%). There is a relationship between experience and the success of cardiopulmonary resuscitation with a $p$ value of 0.0001 .

Suggestions Training for emergency cardiac arrest needs to be carried out routinely to improve the quality of $C P R$
\end{abstract}

Keywords: CPR, nurse, experience, success 


\section{PENDAHULUAN}

Penyakit kardiovaskular merupakan ancaman dunia (global threat) dan menyebabkan kematian nomor satu di seluruh dunia. Data WHO menjelaskan, lebih dari 17 juta jiwa di dunia meninggal dunia yang diakibatkan penyakit jantung dan pembuluh darah. Hasil Riskesdas tahun 2018, menyebutkan bahwa angka kejadian penyakit jantung dan pembuluh darah dari tahun ke tahun terus meningkat. Ada sekitar 2.784.064 orang di Indonesia mengalami penyakit jantung (Firdaus, 2019). Prevalensi penyakit gagal jantung di Indonesia berdasar pada diagnosis dokter sejumlah $1,5 \%$ atau sekitar 29.550 orang. Paling banyak terdapat di provinsi kaltara yaitu 29.340 orang atau sekitar 2,2\% sedangkan yang paling sedikit penderitanya adalah pada provinsi Maluku Utara yaitu sebanyak 144 orang atausekitar 0,3\%.

Penyebab tingginya serangan jantung karena faktor umur. Usia yang bertambah maka risiko terkena Penyakit Jantung semakin meningkat. Untuk lakilaki memasuki usia 45 tahun,dan wanita menjelang usia 55 tahun atau jika mengalami menopause dini. Selain usia juga riwayat keluarga dengan penyakit jantung, Diabetes Melitus, Hipertensi dll (Kemenkes, 2018).

Untuk bisa menurunkan angka kematian akibat henti jantung, maka dibutuhkan penatalaksanaan yang tepat dalam penanganannya. Penanganan yang dikembangkan adalah Resusitasi Jantung Paru (RJP). Hingga saat ini RJP merupakan penatalaksanaan yang sangat vital dalam kasus henti jantung. American Heart Asociation menjelaskan bahwa kejadian henti jantung dapat terjadi di mana dan kapan saja. Tindakan RJP pada saat kejadian dapat mengurangi risikokematian. RJP dan defibrilasi yang diberikan secepatnya, dapat mengakibatkan jantung dapat berdenyut kembali. (AHA, 2015).
Resusitasi Jantung Paru akan memberikan hasil yang paling baik jika dilakukan dalam waktu 5 menit pertamasaat pasien diketahui tidak sadarkan diridengan menggunakan automated external defibrillator (AED) (PERKI, 2020).

Tindakan RJP berkualitas tinggi merupakan bagian terintegrasi dari rantai untuk bertahan hidup dan menjadi landasan dalam pengobatan awal henti jantung sebelum defibrilasi dan bantuan hidup lanjutan. Jika dilakukan denganbenar akan meningkatkan kelangsungan hidup pasien (Pettersen, 2017).

Perawat kardiovaskular perlu memiliki pengetahuan dan ketrampilan dalam melakukan BHD/RJP, yang diperoleh melalui pelatihan danpengalaman yang ditemukan sehari-hari saat melakukan tindakan ini. Faktor yang menentukan kualitas tindakan BHD/RJP adalah usia, jenis kelamin, indeks masa tubuh,kelehan, frekuensi pelatihan yang diikuti (Ardiansya, 2019).

Hasil survey awal yang dilakukan peneliti kepada 2 orang perawat di ruang ICCU RSUD Prof. Dr.W.Z.Johannes kupang didapatkan bahwa perawat sering menemukan pasien yang mengalami cardiac arrest, yang memerlukan tindakan RJP. Hasil tindakan ini bisa menyelamatkan pasien. Hal ini tergantung pada luasnya infark pada jantung. Perawat yang memberikan peertolongan kepada pasien yang mengalami cardiac arrest berasal dari latar belakang pendidikan, lama bekerja, status kepegawaian yang berbeda.Hal ini tentu mempengaruhi keberhasilan dan ketepatan melakukan RJP. di Berdasarkan hal tersebut, perlu dilakukan penelitian tentang hubungan pengalaman dan keberhasilan perawat dalam melakukan resusitasi jantung paru di ruang ICI,ICCU dan IGD RSUD Prof Dr.W.Z.Johannes Kupang. 


\section{METODE PENELITIAN}

Penelitian ini merupakan penelitian kuantitatif dengan rancangan studi korelasi untuk melihat pengalaman perawat dan keberhasilan melakukan Resusitasi jantung paru.

Populasi target dalam penelitian ini adalah semua perawat yang ada di IGD, ICCU dan ICU RSUD Prof. DR. W. Z. Johannes Kupang. Teknik Sampling non probability sampling yakni quota sampling dengan kriteria inklusi Perawat yang aktif bekerja minimal 1 tahun, Pendidikan minimal D-III Keperawatan, telah mengikuti pelatihan minimal BLS.Jumlah Sampel yang memenuhi quota sebanyak 41 orang. Kriteria eksklusi dalam penelitian ini yaitu perawat yang sedang cuti.

Instrumen penelitian adalah kuesioner yag terdiri dari pertanyaan tentang identitas responden, kuesioner pengalaman dengan 16 pertanyaan serta kuesioner keberhasilan RJP yang terdiri dari 5 pertanyaan.

Penelitian dilaksanakan bulan Oktober - Nopember 2020 di di ruang IGD,ICUdan ICCU RSUD Prof.W.Z Johannes Kupang. Data dianalisis secara deskriptif dan analitik menggunakan uji Chi Square untuk menguji hubungan pengalaman perawat dengan keberhasilan resusitasi jantung paru di ruang IGD,ICU dan ICCU RSUD Prof.W.Z Johannes Kupang.

\section{HASIL}

\begin{tabular}{|c|c|c|}
\hline \multicolumn{3}{|c|}{$\begin{array}{c}\text { Tabel 1. Karakteristik Responden } \\
\text { Berdasarkan Umur di ruang } \\
\text { IGD,ICCU,ICU RSUD Prof. Dr. W } \\
\text { Z. Johannes Kupang) } \\
\end{array}$} \\
\hline Umur & $\mathrm{F}$ & $(\%)$ \\
\hline 20-30 tahun & 7 & 19.5 \\
\hline 31-40 tahun & 22 & 53.7 \\
\hline 41-50 tahun & 8 & 19.5 \\
\hline 51-60 tahun & 3 & 7.3 \\
\hline TOTAL & 41 & 100,0 \\
\hline
\end{tabular}

Hasil penelitian menunjukkan bahwa sebagian besar responden berumur 31-40 tahun dengan jumlah 22 orang (53.7\%) dan sebagian kecil berumur 51-60 tahundengan jumlah 3 orang $(7,3 \%)$.

Tabel 2. Karakteristik Responden Berdasarkan Jenis Kelamin di ruang IGD,ICCU,ICU RSUD Prof. Dr. W. Z. Johannes Kupang

\begin{tabular}{ccc}
\hline Jenis Kelamin & F & $(\%)$ \\
\hline Perempuan & 30 & 73.2 \\
\hline Laki-laki & 11 & 26.8 \\
\hline TOTAL & 30 & 100,0 \\
\hline
\end{tabular}

Hasil penelitian menunjukkan bahwa sebagian besar responden berjenis kelamin perempuan yaitu sebanyak 30 orang $(73,2 \%)$.

Tabel 3. Karakteristik Responden Berdasarkan status Kepegawaian di di ruang IGD,ICCU,ICU RSUD

Prof. Dr. W. Z. Johannes Kupang

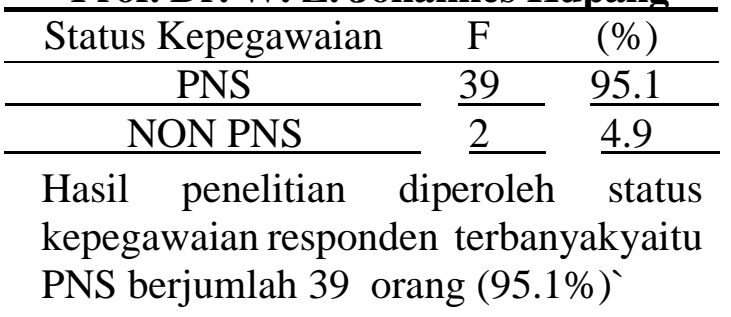

Tabel 4. Karakteristik Responden Berdasarkan PendidikanTerakhir di RSUD Prof. Dr. W. Z. Johannes Kupang

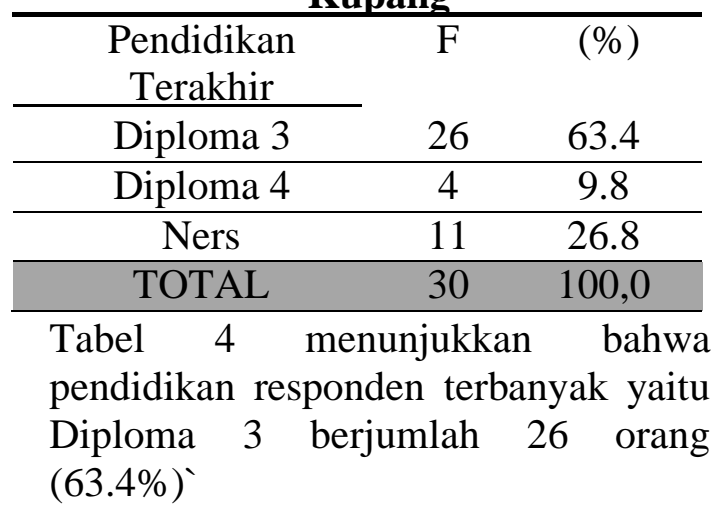


Tabel 5 karakteristik responden berdasarkan lama masa kerja di ruang IGD,ICCU,ICU RSUD Prof. Dr. W. Z. Johannes Kupang

\begin{tabular}{ccc}
\hline Lama Masa kerja & $\mathrm{F}$ & $(\%)$ \\
\hline 1-5 tahun & 10 & 24.4 \\
\hline 6-10 tahun & 17 & 41.5 \\
\hline 11-15 tahun & 7 & 17.1 \\
\hline TOTAL & 30 & 100,0
\end{tabular}

Hasil penelitian menunjukkan bahwa lama bekerja responden terbanyak yaitu 6-10 tahun berjumlah 17 orang $(41.5 \%)$.

Tabel 6 karakteristik responden berdasarkan jenis pelatihan yang pernah diikuti

\begin{tabular}{ccc}
\hline Jenis Pelatihan & $\mathrm{F}$ & $(\%)$ \\
\hline BLS & 17 & 41.5 \\
\hline BTCLS & 7 & 17.1 \\
\hline BLS,BTCLS,PPGD & 5 & 12.2 \\
\hline BLS,BTCLS & 3 & 7.3 \\
\hline ACLS & 2 & 4.9 \\
\hline ACLS,BTCLS & 2 & 4.9 \\
\hline PPGD & 3 & 7.3 \\
\hline TOTAL & 41 & 100,0
\end{tabular}

Hasil penelitian menunjukkan bahwa sebagian besar responden telah mengikuti pelatihan BLS yakni 17 orang (41.5\%).

Tabel 7 karakteristik responden berdasarkan frekuensi melakukan tindakan RJP di ruang

IGD,ICCU,ICU RSUD Prof. Dr. W. Z. Johannes Kupang

\begin{tabular}{ccc}
\hline Frekuensi & $\mathrm{F}$ & $(\%)$ \\
\hline $1-3 \mathrm{kali}$ & 6 & 14.6 \\
\hline $4-6 \mathrm{kali}$ & 13 & 31.7 \\
\hline $7-10 \mathrm{kali}$ & 10 & 24.4 \\
\hline >10 kali & 6 & 14.6 \\
\hline Tidak pernah & 6 & 14.6 \\
\hline TOTAL & 41 & 100,0 \\
\hline
\end{tabular}

Hasil penelitian didapatkan bahwa sebagian besar responden telah mengikuti tindakan Resusitasi Jantung Paru 4-6 kali yakni 13 orang ( $31.7 \%$ ).
Tabel 8 Pengalaman Perawat dalam melakukan resusitasi Jantung Paru di ruang IGD,ICCU,ICU RSUD Prof. Dr. W. Z. Johannes Kupang Pengalaman RJP

\begin{tabular}{cccc}
\hline $\begin{array}{c}\text { Cukup } \\
34-51\end{array}$ & 37 & 90.8 \\
Baik & & \\
51-68 & & 9.2 \\
\hline TOTAL & 41 & 100,0 \\
\hline
\end{tabular}

Hasil penelitian menunjukkan bahwa sebagian besar responden memiliki cukup pengalaman dalam melakukan resusitasi Jantung.

Tabel 9 Keberhasilan Perawat dalam melakukan resusitasi Jantung Paru di ruang IGD,ICCU,ICU RSUD Prof. Dr. W. Z. Johannes Kupang

\begin{tabular}{ccc}
\hline $\begin{array}{l}\text { Keberhasilan perawat } \\
\text { melakukan RJP }\end{array}$ & $\mathrm{F}$ & $(\%)$ \\
\hline Berhasil 16-20 & 34 & 82.9 \\
\hline $\begin{array}{c}\text { Tidak Berhasil } \\
<16\end{array}$ & 7 & 17.1 \\
\hline TOTAL & 41 & 100,0 \\
\hline
\end{tabular}

Hasil penelitian diperoleh sebagian besar responden berhasil melakukn RJP yakni 34 orang ( $82.9 \%)$.

Tabel 10 Hubungan Usia dengan keberhasilan melakukan Resusitasi Jantung Paru di ruang

IGD,ICCU,ICU RSUD Prof. Dr. W. Z. Johannes Kupang

\begin{tabular}{|c|c|c|c|}
\hline \multirow[t]{2}{*}{ Umur } & \multicolumn{2}{|c|}{$\begin{array}{l}\text { Keberhasilan } \\
\text { Melakukan Resusitasi } \\
\text { Jantung Paru }\end{array}$} & \multirow[t]{2}{*}{$\begin{array}{l}\mathrm{P} \\
\text { value }\end{array}$} \\
\hline & $\begin{array}{l}\text { 16-20 : } \\
\text { Berhasil }\end{array}$ & $\begin{array}{l}<16: \\
\text { Tidak }\end{array}$ & \\
\hline 20-30 tahun & $\underline{6}$ & $\underline{2}$ & \multirow[t]{4}{*}{0.001} \\
\hline 31-40 tahun & 17 & 5 & \\
\hline 41-50 tahun & $\underline{8}$ & & \\
\hline 51-60 tahun & 3 & & \\
\hline
\end{tabular}

Hasil penelitian menunjukkan bahwa 17 orang yang berusia 31-40 berhasil melakukan resusitasi jantung paru dan 
terdapat hubungan antara usia dan keberhasilan melakukan RJP dengan tingkat signifikan 0,001 .

Tabel 11 Hubungan Jenis kelamin dengan keberhasilan melakukan Resusitasi Jantung Paru di ruang IGD,ICCU,ICU RSUD Prof. Dr. W. Z. Johannes Kupang

\begin{tabular}{|c|c|c|c|}
\hline \multirow[t]{2}{*}{$\begin{array}{l}\text { Jenis } \\
\text { kelamin }\end{array}$} & $\begin{array}{r}\text { Kebe } \\
\text { Mel } \\
\text { Resusit } \\
\end{array}$ & $\begin{array}{l}\text { hasilan } \\
\text { kukan } \\
\text { si Jantung } \\
\text { aru }\end{array}$ & \multirow[t]{2}{*}{$\begin{array}{l}\mathrm{P} \\
\text { value }\end{array}$} \\
\hline & $\begin{array}{l}16-20: \\
\text { Berhasi } \\
1\end{array}$ & $\begin{array}{l}<16: \\
\text { Tidak }\end{array}$ & \\
\hline Laki-laki & 23 & $\underline{7}$ & 0,01 \\
\hline
\end{tabular}

Hasil penelitian didapatkan bahwa 23 orang laki-laki berhasil melakukan RJP dan ada hubungan antara jenis kelamin dengan keberhasilan melakukan RJP.

Tabel 12 Hubungan pendidikan dengan keberhasilan melakukan Resusitasi Jantung Paru di ruang IGD,ICCU,ICU RSUD Prof. Dr. W. Z. Johannes Kupang

\begin{tabular}{|c|c|c|c|}
\hline \multirow[t]{2}{*}{$\begin{array}{l}\text { Tingkat } \\
\text { pendidikan }\end{array}$} & \multicolumn{2}{|c|}{$\begin{array}{c}\text { Keberhasilan } \\
\text { Melakukan } \\
\text { Resusitasi Jantung } \\
\text { Paru } \\
\end{array}$} & \multirow[t]{2}{*}{$\begin{array}{l}\mathrm{P} \\
\text { value }\end{array}$} \\
\hline & $\begin{array}{l}\text { 16-20: } \\
\text { Berhasil }\end{array}$ & $\begin{array}{l}<16: \\
\text { Tidak } \\
\text { berhasil }\end{array}$ & \\
\hline D3 & 22 & 4 & \multirow[t]{3}{*}{0,001} \\
\hline D4 & 4 & 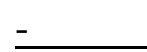 & \\
\hline Ners & $\underline{8}$ & $\underline{3}$ & \\
\hline $\begin{array}{l}\text { Jasil peneli } \\
\text { ang tamat I } \\
\text { nelakukan } \\
\text { endidikan }\end{array}$ & $\begin{array}{l}\text { didapa } \\
\text { ploma } 3 \\
\text { JP dan } \\
\text { deng }\end{array}$ & $\begin{array}{l}\text { bahw } \\
\text { rawat: } \\
\text { hubun } \\
\text { ke }\end{array}$ & $\begin{array}{l}\text { orang } \\
\text { erhasil }\end{array}$ \\
\hline
\end{tabular}

Tabel 13 Hubungan status kepegawaian dengan keberhasilan melakukan Resusitasi Jantung Paru di ruang IGD,ICCU,ICU RSUD Prof. Dr. W. Z. Johannes Kupang

\begin{tabular}{|c|c|c|c|}
\hline \multirow[t]{2}{*}{$\begin{array}{l}\text { Status } \\
\text { kepegawaia } \\
\mathrm{n}\end{array}$} & \multicolumn{2}{|c|}{$\begin{array}{c}\text { Keberhasilan } \\
\text { Melakukan } \\
\text { Resusitasi } \\
\text { Jantung Paru }\end{array}$} & $\begin{array}{l}\mathrm{P} \\
\text { value }\end{array}$ \\
\hline & $\begin{array}{c}\text { 16-20 : } \\
\text { Berhasi } \\
1\end{array}$ & $\begin{array}{c}<16: \\
\text { Tidak } \\
\text { berhasi } \\
1\end{array}$ & \\
\hline Non PNS & 32 & 7 & $\begin{array}{l}0,000 \\
1\end{array}$ \\
\hline Non PNS & 2 & & \\
\hline
\end{tabular}

\section{Tabel 14 Hubungan lama masa kerja dengan keberhasilan melakukan Resusitasi Jantung Paru di ruang} IGD,ICCU,ICU RSUD Prof. Dr. W. Z. Johannes Kupang

\begin{tabular}{|c|c|c|c|}
\hline \multirow[t]{2}{*}{$\begin{array}{l}\text { Lama masa } \\
\text { kerja }\end{array}$} & \multicolumn{2}{|c|}{$\begin{array}{c}\text { Keberhasilan } \\
\text { Melakukan } \\
\text { Resusitasi } \\
\text { Jantung Paru }\end{array}$} & \multirow[t]{2}{*}{$\begin{array}{l}\mathrm{P} \\
\text { value }\end{array}$} \\
\hline & $\begin{array}{c}\text { 16-20: } \\
\text { Berhasil }\end{array}$ & $\begin{array}{c}<16: \\
\text { Tidak } \\
\text { berhasil } \\
\end{array}$ & \\
\hline 1-5 tahun & 8 & 2 & \multirow[t]{5}{*}{0,0001} \\
\hline 6-10 tahun & 13 & 4 & \\
\hline 11-15 tahun & 7 & - & \\
\hline 16-20 tahun & 3 & - & \\
\hline 21-25 tahun & 1 & - & \\
\hline $\begin{array}{l}\text { Hasil penelit } \\
\text { orang yang } \\
\text { berhasil melal } \\
\text { antara lama m }\end{array}$ & $\begin{array}{l}\text { didap } \\
\text { dah be } \\
\text { kan RJP } \\
\text { a kerja d }\end{array}$ & $\begin{array}{l}\text { xan bah } \\
\text { rja 6-10 } \\
\text { an ada hı } \\
\text { gankebe }\end{array}$ & $\begin{array}{l}\text { wa } 13 \\
\text { tahun }\end{array}$ \\
\hline
\end{tabular}


Tabel 15 Hubungan jenis pelatihan kegawatdaruratan dengan

keberhasilan melakukan Resusitasi Jantung Paru di ruang

IGD,ICCU,ICU RSUD Prof. Dr. W. Z. Johannes Kupang

\begin{tabular}{|c|c|c|}
\hline \multirow[t]{2}{*}{ Jenis Pelatihan } & $\begin{array}{c}\text { Keberhasilan } \\
\text { Melakukan } \\
\text { Resusitasi Jantung } \\
\text { Paru } \\
\end{array}$ & $\begin{array}{l}\mathrm{P} \\
\text { valu } \\
\mathrm{e}\end{array}$ \\
\hline & $\begin{array}{cc}\text { 16-20: } & <16: \\
\text { Berhasi } & \text { Tidak } \\
1 & \text { berhasil } \\
\end{array}$ & \multirow{8}{*}{$\begin{array}{l}0,00 \\
01\end{array}$} \\
\hline BLS & 15 & \\
\hline BTCLS & 7 & \\
\hline $\begin{array}{l}\text { BLS,BTCLS,PP } \\
\text { GD }\end{array}$ & 5 & \\
\hline BLS,BTCLS & 3 & \\
\hline ACLS & 2 & \\
\hline ACLS,BTCLS & 1 & \\
\hline PPGD & $\underline{1}$ & \\
\hline $\begin{array}{l}\text { Hasil penelitian } \\
\text { orang yang sudah } \\
\text { BLS berhasil me } \\
\text { hubungan } \\
\text { kegawatdaruratan } \\
\text { melakukan RJP. }\end{array}$ & $\begin{array}{l}\text { didapatkan bahwa } \\
\text { mendapatkan pelatil } \\
\text { elakukan RJP dan } \\
\text { antara } \\
\text { dengan keberhasi }\end{array}$ & $\begin{array}{l}15 \\
\text { han } \\
\text { ada } \\
\text { han } \\
\text { lan }\end{array}$ \\
\hline
\end{tabular}

Tabel 16 Hubungan frekuensi melakukan RJP dengan

keberhasilan melakukan Resusitasi Jantung Paru di ruang

IGD,ICCU,ICU RSUD Prof. Dr. W. Z. Johannes Kupang

\begin{tabular}{|c|c|c|c|}
\hline \multirow[t]{2}{*}{$\begin{array}{l}\text { Frekuensi } \\
\text { RJP }\end{array}$} & \multicolumn{2}{|c|}{$\begin{array}{c}\text { Keberhasilan } \\
\text { Melakukan } \\
\text { Resusitasi } \\
\text { Jantung Paru }\end{array}$} & $\begin{array}{l}\mathrm{P} \\
\text { value }\end{array}$ \\
\hline & $\begin{array}{c}\text { 16-20 : } \\
\text { Berhasil }\end{array}$ & $\begin{array}{c}<16: \\
\text { Tidak } \\
\text { berhasil }\end{array}$ & \\
\hline 1-3 Kali & $\underline{4}$ & $\underline{2}$ & 0,0001 \\
\hline 4-6 kali & $\underline{11}$ & $\underline{2}$ & \\
\hline $7-10$ kali & 9 & 1 & \\
\hline$>10$ kali & 3 & - & \\
\hline
\end{tabular}

melakukan RJP dan ada hubungan antara frekuensi melakukan RJP dengan keberhasilan melakukan RJP.

\section{PEMBAHASAN}

Hasil penelitian didapatkan bahwa sebagian besar responden memiliki pengalaman yang cukup dalam melakukan resusitasi Jantung Paru. Pengalaman terbentuk dari tingkat pengetahuan dan pendidikan seseorang, pelaku atau faktor pada pihak yang mempunyai pengalaman, faktor obyek atau target yang dipersepsikan dan faktor situasi dimana pengalaman itu dilakukan. Umur, tingkat pendidikan, pekerjaan, kepribadian dan pengalaman hidup.

Pengalaman perawat melakukan resusitasi jantung paru di RSUD Prof,Dr.W.Z.Johannes Kupang terbentuk dari tingkat pendidikan yakni sebagian besar berijazah Diploma III Keperawatan. Pada tingkat ini kompetensi keperawatan gawat darurat yang didapatkan saat kuliah meliputi kemampuan untuk melakukan Resusitasi Jantung paru dan telahmengikuti pelatihan BLS ( Basic lifesupport ). Usia perawat yang bekerja di IGD,ICU dan ICCU sebagian besar beradapada rentang 31-40 tahun. Ini merupakan rentang usia dewasa yang memiliki tanggung jawab sosial dan kemanusiaan, mempunyai.

Hasil penelitian yang menunjukkan bahwa perawat DI IGD, ICU dan ICCU RSUD Prof Dr.W.Z.Johannes memiliki pengalaman yang cukup dalam melakukan RJP. Penelitian yang dilakukan Lee danCha tahun 2017 mendapatkan bahwa perawat yang telah memiliki pengalaman melakukan RJP, pelatihan-pelatihan pengalaman cemas saat melakukan RJP, sebagai akibat situasi mendadak yang dihadapi saat menanganai pasien yang kondisi cardiac arrest dan perlu RJP. 
Dengan melakukan tindakan RJP perawat semakin memiliki pengalaman akan prosedur tindakan ini, sehingga dapat meningkatkan kinerja perawat. Selama melakukan RJP, perawat selalu berusaha melakukan yang terbaik, walaupun terdapat konflik batin akibat kecemasan tidak bisa menyelamatkan pasien. Namun memiliki keuntungan bahwa perawat bisa mengembangkan kompetensi untuk melakukan RJP (Lee \& Cha, 2017). Hasil penelitian Nori et al didapatkan bahwa pelatihan atau kursus akan meningkatkan kompetensi perawat dalam melakukan RJP (Nori, 2011)

Hasil penelitian diperoleh sebagian besar responden berhasil melakukan resusitasi jantung paru. Faktor yang mempengaruhi keberhasilan di IGD\, ICU dan ICCU RSUD Prof Dr.W.Z.Johannes adalah RJP perawat telah mengikuti pelatihan BLS dan sebagain besar telah mengikuti pelatihan di tingkat mahir yakni BTCLS,ACLS. Hasil ini didukung oleh penelitian yang dilakukan Fakhrul tahun 2019 yang mendapatkan hasil bahwa ada hubungan antara frekuensi pelatihan dengan kualitas kompresi RJP. Frekuensi pelatihan kategori baik mampu meningkatkan kognitif dan skill melalui belajar observasional selama pelatihan, sehingga individu akan koreksi diri untuk meningkat kualitas kompresi RJP (Ardiansyah, 2019). Selain itu frekuensi melakukan RJP dalam waktu 6 bulan terakhir ( Januari s.d September 2020 ) sebagian besar 4-6 kali.

Hasil penelitian Andersonet al tahun 2019 didapatkan pelatihan CPR berdurasi pendek setiap bulan menggunakan boneka secara nyata efektif dalam meningkatkan performa CPR, dengan pelatihan bulanan dibandingkan pelatihan setiap 3, 6, atau 12 bulan (Anderson, 2019).
Pelatihan resusitasi tetap menjadi bagian penting dari perawatan pendidikan dan membutuhkan masukan yang tepat untuk memastikan perawat itu merasa dan bertindak secara kompeten saat menghadapi serangan jantung korban. Pengetahuan dan keterampilan perawat tentang RJP sangat penting untuk bisa menurunkan angka kematian pasien akibat serangan jantung

Hasil penelitian didapatkan usia, jenis kelamin, tingkat pendidikan status kepegawaian, lama masa kerja, pelatihan kegawatdauratan yang pernah diikuti, frekuensi melakukan RJP sejak bulan Januari s.d September 2020 para perawat yang bekerja di ruang ICU, IGD dan ICCU RSUD Prof.Dr.W.Z.Johannes Kupang memiliki hubungan dengan keberhasilan tindakan resusitasi jantung paru.

Hasil penelitian ini didukung oleh Fakrul yang menjelaskan bahwa terdapat hubungan yang bermakna antara usia dengan kualitas kompresi. Penelitian lain rentang usia 23-35 tahun memiliki performa yang baik dalam kompresi dada kedalaman $5 \mathrm{~cm}$ dengan proporsi $80 \%$ (Ardiansyah, 2019).

Hasil uji statistik menunjukkan bahwa terdapat hubungan yang bermakna antara jenis kelamin dengan kualitas kompresi RJP $\quad(p=0,001 ; \alpha$ penelitian mendukung penelitian pada 84 mahasiswa kedokteran melakukan RJP pada manekin selama 2 menit didapatkan bahwa laki-laki efektif mencapai kedalaman kompresi dada yang adekuat dibandingkan dengan perempuan. Laki- laki memiliki peluang kompresi dada berkualitas 3,85 kali lebih besar dibandingkan perempuan. Kompresi dada adekuat dapat mengoptimalkan cardiac. Penelitian Yu Jeong Kim • Eun Mi Lee tahun 2017 menjelaskan bahwa Ada korelasi positif antara kepercayaan diri terhadap kinerja pengetahuan dan 
sikap.Semakin positif sikap siswa dalam melakukan RJP ,semakin tinggi kepercayaan terhadap CPR. Faktor yang mempengaruhi kepercayaan pada resusitasi paru adalah pengetahuan, nilai, jumlah pelatihan praktis CPR, dan kepuasan pendidikan. Semakin tinggi faktor-faktor tersebut, semakin tinggi kepercayaan terhadap kinerjanya (Kim \& Lee, 2017)

Kesiapan perawat dalam penanganan cardiac arrest dipengaruhi oleh beberapa faktor, yaitu pengetahuan yang cukup dari perawat tentang penanganan situasi kegawatan, pengalaman yang memadai, peraturan atau protokol yang jelas, sarana dan suplai yang cukup, serta pelatihan atau training tentang penanganan situasi kegawatan.

Perawat sebagai seorang profesional diperlukan kesadaran diri tinggi pada situasi henti jantung di rumah sakit. Kesadaran diri diperlukan sebagai evaluasi diri, evaluasi kegagalan diri, antisipasi penyebab kegagalan, dan keinginan kuat yang konsisten untuk memperbaiki diri sehingga kesadaran diri seseorang akan meningkat (Duval, Silvia, \& Lalwani, 2001). Peneliti berpendapat bahwa kesadaran diri perawat yang tinggi terhadap situasi gawat mampu meningkatkan motivasi dan kepercayaan diri untuk melakukan kompresi sehingga kompresi berkualitas tinggi dapat dicapai

\section{SIMPULAN}

Hasil penelitian didapatkan bahwa sebagian besar responden memiliki cukup pengalaman dalam melakukan resusitasi Jantung Paru.Sebagian besar perawat berhasil melakukan resusitasi jantung paru. Ada hubungan yang signifikan antara pengalaman dengan keberhasilan tindakan RJP. Pelatihan penanganan kegawatdaruratan henti jantung perlu dilaksanakan rutin untuk meningkatkan kualitas RJP. Kriteria inklusi diperketat. Lebih akurat jika menggunakan lembar observasi untuk menilai keberhasilan melakukan RJP. Alat ukur perlu dirincikan tentang waktu tanggap darurat, penanganan yang pernah dilakukan sebelum RJP.

\section{REFERENSI}

Al, N. E. (2011, Pebruari). CPR Training For Nurses: How Often Is It Necessary? Iranian Red Crescent Medical Journal, 4, 10-107.

Anderson, R. E. (2019). Optimal Training Frequency For Acquisition And Retention Of High-Quality Cpr Skills: A Randomized Trial.

Resuscitatio, 153-161. Doi:Https://Doi.Org/10.1016/J.Res uscitation.2018.10.033

Ardiansya, F. E. (2019, Pebruari). Faktor Penentu Kualitas Kompresi Resusitasi Jantung Paru Oleh Perawat. Jurnal 'Aisyiyah Medika, 3, 123-137.

Ardiansyah, F. E. (2019, Pebruari). Faktor Penentu Kualitas Kompresi Resusitasi Jantung Paru Oleh Perawat. Jurnal 'Aisyiyah Medika, 3, 123-137.

Balitbangkes. (2018).

Https://Www.Kemkes.Go.Id/Resour ces/Download/Info-Terkini/Hasil-

Riskesdas-2018.Pdf. Dipetik

Desember 01, 2019, Dari Https://Www.Kemkes.Go.Id/Resou rces/Download/Info-Terkini/HasilRiskesdas-2018.Pdf

Bayu Budi Laksono, A. W. (2018). Prinsip Dan Aplikasi Dasar Kegawatdaruratan Jantung Paru. Yogyakarta: Pustaka Pelajar.

Boswick, J. A. (1988). Perawatan Gawat

Darurat. Jakarta : Egc. 
Dahlan, S., \& Kumaat, L. (2014).

Pengaruh Pendidikan Kesehatan Tentang Bantuan Hidup Dasar (Bhd) Terhadap Tingkat Pengetahuan Tenaga Kesehatan Di Puskesmas Wori. Ejurnal Keperawatan .

Dahlan, S., \& Kumaat, L. (2014).

Pengaruh Pendidikan Kesehatan

Tentang Bantuan Hidup

Dasarterhadap Tingkat

Pengetahuan Tenagaa Di

Puskesmas Wori. Ejurnal Keperawatan .

Dr. Dr. Isman Firdaus Sp.Jp (K), F. F.

(2019, September 27).

Http://Www.Inaheart.Org/. Dipetik

Desember 10, 2019, Dari

Http://Www.Inaheart.Org/News_A nd_Events/News/2019/9/26/Press_

Release_World_Heart_Day_Perki_ 2019

Dr. Karmel L. Tambunan, D. I. (1990).

Buku Panduan Penatalaksanaan

Gawat Darurat. Jakarta : Fakultas

Kedokteran Universitas Indonesia.

Firdaus, I. (2019). Hari Jantung Sedunia (World Heart Day): Your Heart Is Our Heart Too. Jakarta: Perki.

Dipetik Nopember 30, 2020, Dari

Http://Www.Inaheart.Org/News_A nd_Events/News/2019/9/26/Press_

Release_World_Heart_Day_Perki_ 2019

Fkui, T. B. (T.Thn.). Modul Bantuan

Hidup Dasar Dan Penanganan

Tersedak.

Ganthikumar, K. (2016). Indikasi Dan

Keterampilan Resusitasi Jantung

Paru. Intisari Sains Medis .

Gosal, A., \& Nada, I. K. (2017). Bantuan

Hidup Dasar. Sanglah: Bagian/Smf

Ilmu Anastesi Dan Terapi Intensif

Fakultas Kedokteran Universita

Udayana.

Gosal, A., \& Nada, I. K. (2017). Bantuan

Hidup Dasar . Sanglah :

Bagian/Smf Ilmu Anstesi Dan

Terapi Intensif Fakultas Kesehatan

Universitas Udayana .
Hamarno, R. (2016). Keperawatan Gawat Darurat Dan Manajemen Bencana. Jakarta.

Hospital, L. S. (2017). Modul Pelatihan Basic Cardiac Life Support Program Pelatihan Bantuan Hidup Dasar. Surabaya.

Irfani, Q. (2019). Bantuan Hidup Dasar . Majelis Kesehatan Ranting Aisyiyah Kertonatan.

Irhash Faisal Ramsi, M. E. (2016). Basic Life Support. Jakarta: Buku Kedokteran Egc.

Irhash Faisal Ramsi, M. E. (2016). Basic Life Support. Jakarta: Buku Penerbit Kedokteranegc.

Irhash Faisal Ramsi, M. E. (2016). Basic Life Support . Jakarta : Buku Kedokteran Egc.

John A. Boswick, I. (1997). Perawatan Gawat Darurat . Jakarta : Buku Kedokteran Egc.

Kemenkes, P. (2018). Faktor Pemicu Gejala Serangan Jantung. Jakarta: Direktorat Pencegahan Dan Pengendalian Penyakit Tidak Menular. Dipetik Nopember 30, 2020, Dari Http://P2ptm.Kemkes.Go.Id/Infogr aphic-P2ptm/Hipertensi-PenyakitJantung-Dan-PembuluhDarah/Faktor-Pemicu-GejalaSerangan-Jantung

Kim, Y. J., \& Lee, E. M. (2017, Desember). Influencing Factors Of Confidence In Performing Cardiopulmonary Resuscitation (Cpr) Among University Students. J Korean Soc Sch Health, 30, 194201.

Doi:Https://Doi.Org/10.15434/Kss h.2017.30.3.194

Kumar, K. (2016). Indikasi Dan Keterampilan Rjp. Intisari Sains Medis .

Kurniati, A., Trisyani, Y., \& Theresia, S. I. (2018). Keperawatan Gawat Darurat Dan Bencana Sheehy. Indonesia. 
Lee, M.-R., \& Cha, C. (2017). Emergency Department Nurses' Experience Of Performing Cpr In South Kores. International Emergency Nursing. Doi:Http://Dx.Doi.Org/10.1016/J.I enj.2017.09.008

Medan, P. (2020). Pelatihan Bantuan Hidup Dasar (Bhd). Medan: Perki Medan. Diambil Kembali Dari Https://Perkimedan.Org/Portfolio/ Http-Perkimedan-Org-PortfolioWork-Space/

Medis, T. B. (2015). Modul Bantuan Hidup Dasar Dan Penanganan Tersedak. Jakarta : Bem Ikm Fkui.

Melisa, R. (2019). Pengetahuan Perawat Tentang Primary Survey (Penilaian Awal) Pada Pasien Gawat Darurat Di Instalasi Gawat Darurat (Igd) Rsud. Dr. Pirngadi Medan, 23-31.

Muttaqin, A. (2019). Pengantar Asuhan Keperawatan Klien Dengan Gangguan Sistem Kardiovaskule. Jakarta: Salemba Medika.

Nori, J. M. (2011, Pebruari). Cpr Training For Nurses: How Often Is It Necessary? Iranian Red Crescent Medical Journal, 104-107.

Pamela S.Kidd, P. A. (2010). Pedoman Keperawatan Emergensy Edisi 2. Jakarta : Buku Kedokteran Egc.

Perki. (2020). Pelatihan Bantuan Hidup Dasar (Bhd). Perhimpunan Dokter Spesialis Kardiovaskular Indonesia Cabang Medan. Diambil Kembali Dari Https://Perkimedan.Org/Portfolio/ Http-Perkimedan-Org-PortfolioWork-Space/

Pettersen, T. R. (2017). European Cardiovascular Nurses And Allied Professionals Knowledge And Practical Skills Regarding Cardiopulmonary Resuscitation . European Journal of Cardiovascular Nursing, 1-.

Ri, P. K. (2018, Oktober 01).

Http://P2ptm.Kemkes.Go.Id/Infogr aphic-P2ptm/Hipertensi-PenyakitJantung-Dan-Pembuluh-
Darah/Faktor-Pemicu-Gejala-

Serangan-Jantung. Dipetik

Desember 01, 2019, Dari Http://P2ptm.Kemkes.Go.Id/Infogr aphic-P2ptm/Hipertensi-PenyakitJantung-Dan-PembuluhDarah/Faktor-Pemicu-GejalaSerangan-Jantung

Winarni, S. (2017). Pengetahuan Perawat Tentang Bantuan Hidup Dasar Berdasarkan Aha Tahun 2015 Di Uptd Puskesmas Blitar . Jurnal Ners Dan Kebidanan .

Yarsa, K. Y., \& Wiyono, N. (2019). Pedoman Keterampilan Klinis Accident And Emergency. Surakarta.

Yoyos Dias Ismiarto, Y. P. (2019). Faktor Resiko Potensial Terhadap Kematian Pada Pasien Pelvic Ring Injury Yang Dirawat Di Rsup Dr Hasan Sadikin Bandung. Volume 9 